\title{
PENGARUH STRATEGI CONCRETE REPRESENTATIONAL ABSTRACT (CRA) TERHADAP PEMAHAMAN KONSEP MATEMATIKA SISWA KELAS VII SMP NEGERI 3 DAWAN
}

\author{
N. K. S. W. Lestari, G.Suweken, I W. P. Astawa \\ Program Studi Pendidikan Matematika Jurusan Matematika \\ Universitas Pendidikan Ganesha \\ Singaraja, Indonesia \\ e-mail : sriwidya lestari@yahoo.com,gdsuweken5@gmail.com, \\ iwp.astawa@yahoo.co.id
}

\begin{abstract}
Abstrak
Penelitian ini bertujuan untuk mengetahui apakah pemahaman konsep matematika siswa yang mengikuti pembelajaran dengan strategi Concrete Representational Abstract (CRA) lebih baik daripada pemahaman konsep matematika siswa yang mengikuti pembelajaran dengan strategi pembelajaran konvensional. Populasi pada penelitian ini adalah seluruh siswa kelas VII SMP Negeri 3 Dawan tahun 2017/2018. Pengambilan sampel dilakukan dengan teknik cluster random sampling. Sampel dalam penelitian ini adalah siswa kelas VII A sebagai kelompok eksperimen dan siswa kelas VII C sebagai kelompok kontrol. Desain penelitian yang digunakan dalam penelitian ini adalah Post-test Only Control Group Design. Data tes pemahaman konsep matematika siswa dianalisis dengan menggunakan uji- $t$ satu arah dengan taraf signifikansi $5 \%$. Hasil uji hipotesis menunjukkan bahwa pemahaman konsep matematika siswa yang mengikuti pembelajaran dengan strategi Concrete Representational Abstract (CRA) lebih baik daripada pemahaman konsep matematika siswa yang mengikuti pembelajaran dengan strategi pembelajaran konvensional (thitung $(2,9418)>$ tabel $(1,9996))$. Dengan demikian, penerapan strategi Concrete Representational Abstract (CRA) memberikan pengaruh positif terhadap pemahaman konsep matematika siswa.
\end{abstract}

Kata kunci: Concrete Representational Abstract (CRA), pemahaman konsep matematika

\begin{abstract}
This research aims to find out whether the students' conceptual understanding of mathematics who learned with Concrete Representational Abstract (CRA) learning strategy is higher than students' conceptual understanding of mathematics who learned with conventional learning strategy. The population of this reasearch were all the students of grade VII at SMP Negeri 3 Dawan in academic year 2017/2018. The sample was taken by using cluster random sampling technique. Sample of this research were the students in VII A class as the experimental group and VII C as control group. The design of research that used in this research is the Post-test Only Control Group Design. The data of students' conceptual understanding of mathematics was analyzed by using one tail t-test with $5 \%$ significance level. The result of hypothesis test showed that the students' conceptual understanding of mathematics who learned with Concrete Representational Abstract (CRA) learning strategy is better than students' conceptual understanding of mathematics who learned with conventional learning strategy $\left(t_{\text {count }}(2,9418)>t_{\text {table }}(1,9996)\right)$. Thus, the implementation of Concrete Representational Abstract (CRA) learning strategy gives a postive influence on the students' conceptual understanding of mathematics.
\end{abstract}

Keywords: Concrete Representational Abstract (CRA), Conceptual understanding of mathematics 


\section{PENDAHULUAN}

Pembangunan di Indonesia antara lain diarahkan untuk meningkatkan kualitas sumber daya manusia. Sumber daya manusia yang berkualitas bisa dibentuk melalui peningkatan mutu pendidikan. Dalam era globalisasi ini yang identik dengan perkembangan ilmu pengetahuan dan teknologi, sumber daya manusia yang berkualitas akan menjadi tumpuan utama agar suatu bangsa dapat berkompetisi. Segala upaya yang bertujuan meningkatkan mutu pendidikan perlu mendapat perhatian serius dalam pelaksanaannya.

Penyempurnaan kurikulum merupakan salah satu upaya pemerintahan dalam meningkatkan mutu pendidikan di Indonesia. Upaya penyempurnaan kurikulum yang dilakukan pemerintah bertujuan untuk menghadapi perkembangan IPTEK yang pesat dan perubahan yang terjadi begitu cepat. Karena itu diperlukan kemampuan untuk memperoleh, mengelola dan memanfaatkan IPTEK untuk bertahan pada keadaan yang selalu berubah, tidak pasti dan kompetitif. Kemampuan ini membutuhkan pemikiran yang bersifat sistematis, logis, dan kritis yang dapat dikembangkan melalui pembelajaran matematika.

Matematika merupakan ilmu pengetahuan yang banyak diterapkan dalam kehidupan. Menurut Johnson dan Myklebust (dalam Agustin, 2011:47) "matematika adalah bahasa simbolis yang fungsi praktisnya untuk mengekspresikan hubungan - hubungan kuantitatif dan keruangan sedangkan fungsi teoritisnya adalah memudahkan berfikir". Hudojo (2003:123) mengatakan "matematika merupakan suatu ilmu yang berhubungan atau menelaah bentuk - bentuk atau struktur - struktur yang abstrak". Matematika merupakan ilmu pengetahuan dasar yang konsepnya terkandung dalam bidang pengetahuan lain. Pada hakikatnya matematika merupakan ilmu yang terstruktur, dimana konsep - konsep matematika tersusun secara logis dan sistematis mulai dari konsep yang paling sederhana sampai pada konsep yang paling kompleks.
Mengingat pentingnya matematika dalam berbagai aspek kehidupan,sangat diharapkan siswa di setiap jenjang pendidikan memiliki kemampuan matematika yang baik. Pendidikan matematika pada jenjang pendidikan dasar merupakan pondasi bagi penguasaan materi Matematika pada jenjang selanjutnya. Oleh karena itu, pada jenjang pendidikan SD dan SMP perlu dibangun pondasi matematika yang kokoh.

Berdasarkan Permendiknas No. 22 Tahun 2006, mata pelajaran matematika bertujuan agar peserta didik memiliki kemampuan berikut.

a. Memahami konsep matematika, menjelaskan keterkaitan antar konsep dan mengaplikasikan konsep atau algoritma, secara luwes, akurat, efisien, dan tepat dalam pemecahan masalah.

b. Menggunakan penalaran pada pola dan sifat, melakukan manipulasi matematika dalam membuat generalisasi, menyusun bukti, atau menjelaskan gagasan dan pernyataan matematika.

c. Memecahkan masalah yang meliputi kemampuan memahami masalah, merancang model matematika, menyelesaikan model dan menafsirkan solusi yang diperoleh.

d. Mengomunikasikan gagasan dengan simbol, tabel, diagram, atau media lain untuk memperjelas keadaan atau masalah.

e. Memiliki sikap menghargai kegunaan matematika dalam kehidupan, yaitu memiliki rasa ingin tahu, perhatian, dan minat dalam mempelajari matematika, serta sikap ulet dan percaya diri dalam pemecahan masalah.

(Depdiknas,2006:140)

Sejalan dengan tujuan tersebut, jelas bahwa matematika bertujuan agar siswa memiliki kemampuan pemahaman konsep dalam memecahkan masalah. Namun untuk mencapai pemahaman terhadap suatu konsep bagi siswa bukanlah hal yang mudah.

Dilihat juga dari nilai rata rata UN (Ujian Nasional) matematika tingkat SMP se-Kabupaten Klungkung pada tabel di bawah. 
Tabel 1.1 Nilai Rata-rata UN Matematika Tingkat SMP se-Kabupaten Klungkung

\begin{tabular}{c|c}
\hline Tahun Ajaran & $\begin{array}{c}\text { Nilai Rata-rata UN } \\
\text { Matematika }\end{array}$ \\
\hline $2013 / 2014$ & 64,86 \\
\hline $2014 / 2015$ & 43,32 \\
\hline $2015 / 2016$ & 33,36 \\
\hline
\end{tabular}

(Sumber: Dinas Pendidikan Kabupaten Klungkung)

Terlihat bahwa nilai UN matematika tingkat SMP se-Kabupaten Klungkung dari tahun ke tahun mengalami penurunan. Penurunan nilai UN ujian nasional matematika tingkat SMP se-Kabupaten Klungkung ini juga merupakan bukti bahwa nilai matematika yang diperoleh siswa masih rendah, sehingga menyebabkan ketidaklulusan siswa dalam ujian nasional matematika. Penyebab hal tersebut terjadi diduga karena siswa belum memiliki pemahaman konsep yang baik, sehingga belum bisa menyelesaikan soal-soal yang dituntut dalam tes UN yang diadakan. Dengan demikian, salah satu kemampuan yang perlu dikembangkan dengan optimal guna mencapai tujuan pembelajaran matematika adalah pemahaman konsep matematika.

Pemahaman konsep dalam proses belajar mengajar sangat mempengaruhi sikap, keputusan, dan cara-cara memecahkan masalah. NCTM Principles and Standards for School Mathematics (2000) menyatakan, "Students must learn mathe-matics with understanding, actively building new knowledge from experience and prior knowledge." Artinya, siswa harus belajar matematika dengan pemahaman, secara aktif membangun pengetahuan baru dari pengalaman dan pengetahuan sebelumnya.

Pemahaman konsep merupakan salah satu aspek penting dalam pembelajaran matematika, namun pada kenyataannya kemampuan pemahaman konsep siswa belum mendapat perhatian yang optimal. Pada pembelajaran di kelas, siswa jarang diberikan kesempatan untuk mengkonstruksi pengetahuaanya sendiri, sehingga siswa mengalami kesulitan memahami dan memaknai apa yang dipelajari. Dalam menyelesaikan soal, siswa cenderung terpaku pada contoh-contoh penyelesaian yang diberikan oleh guru, sehingga ketika diberikan variasi soal yang berbeda siswa tidak paham bagaimana menyelesaikan soal tersebut. Pemahaman konsep siswa dapat dioptimalkan dengan cara merencanakan dan menyusun baik perencanaan, media, dan bahan ajar untuk direalisasikan dalam kegiatan pembelajaran. Agar konsep-konsep dan teorema-teorema dapat diaplikasikan ke situasi yang lain, perlu adanya keterampilan menggunakan konsep-konsep dan teorena-teorema tersebut. Oleh karena itu, pembelajaran matematika harus ditekankan kearah pemahaman konsep.

Pentingnya pemahaman konsep matematika yang harus dimiliki siswa, maka diperlukan suatu strategi yang mampu meningkatkan pemahaman konsep matematika. Menurut Suryani dan Agung (2012), prinsip strategi pembelajaran salah satunya menekankan pada aktivitas. Belajar bukanlah menghafal sejumlah fakta atau informasi. Belajar adalah berbuat, memperoleh pengalaman tertentu sesuai dengan tujuan yang diharapkan. Oleh karena itu, strategi pembelajaran harus dapat mendorong aktivitas siswa, baik aktivitas fisik maupun aktivitas mental.

Dengan demikian guru perlu menerapkan suatu strategi khusus untuk menciptakan suatu pembelajaran yang efektif yang dapat meningkatkan pemahaman konsep matematika siswa serta dapat memfasilitasi siswa. Strategi tersebut meliputi langkah - langkah guru dalam penyampaian materi, dan bagaimana peranan guru untuk membelajarkan siswa. Strategi yang dapat digunakan oleh guru untuk memfasilitasi adalah strategi Concrete Representational Abstract.

Concrete Representational Abstract merupakan strategi dalam pembelajaran matematika yang memiliki langkah - langkah pembelajaran yang dapat mendorong siswa membangun pondasi pengetahuan matematika mereka secara bertahap sesuai perkembangan cara berfikir siswa dengan lebih baik. Concrete Representational Abstract adalah suatu strategi yang memiliki tiga tahapan pembelajaran yang memungkinkan guru menggunakan benda - 
benda nyata untuk tahap awal atau tahap concrete bagi siswa untuk membuat suatu model permasalahan dilanjutkan tahap Representational (seperti menggambar grafik, diagram), dimana pembelajaran melalui tahap ini menggunakan manipulasi benda nyata dan yang terakhir adalah tahap Abstract atau simbolis (seperti angka, notasi, atau simbol matematika lainnya).

$$
\text { Melalui strategi Concrete }
$$

Representational Abstract ini peneliti menduga bahwa pemahaman konsep matematika siswa dapat meningkat. Hal tersebut dapat dilihat dari keterkaitan antara langkah - langkah strategi Concrete Representational Abstract dengan indikator pemahaman konsep yaitu 1) Concrete yaitu Guru memberikan suatu permasalahan melalui manipulasi benda nyata, kemudian siswa mengidentifikasi konsep yang terdapat pada masalah tersebut. Dalam proses mengidentifikasi siswa sudah mulai penasaran dan mau membuka pikirannya, dimana siswa sudah mulai mengaitkan permasalahan yang diberikan dengan materi matematika yang akan dibahas; 2) Representational yaitu Guru akan meminta siswa untuk menyatakan konsep yang terdapat pada masalah tersebut dengan gambar, grafik atau diagram berdasarkan permasalahan nyata yang diberikan diawal. Ketika siswa sudah bisa menyatakan konsep tersebut dengan menggambar sesuatu dari permasalahan yang didapat diawal berarti siswa sudah memahami suatu konsep, dimana siswa akan mudah menentukan contoh dan bukan contoh dari konsep tersebut; 3) Abstract yaitu pada tahap ini siswa sudah bisa mengaplikasikan atau menggunakan konsep dengan benar dalam berbagai situasi seperti siswa sudah mahir dalam menyelesaikan permasalahan awal dalam bentuk simbol matematika. Melalui langkah - langkah pembelajaran tersebut nantinya siswa akan diantarkan pada penemuan konsep - konsep matematika, serta mengorganisasikan mereka untuk menyelesaikan permasalahan yang dihadapi. Dengan strategi ini, siswa dapat mempraktikkan dan mendemonstrasikan dirinya untuk mencapai kemampuan pemahaman konsep matematika. Aktivitas yang langsung dikerjakan oleh siswa dapat membantu pemahaman materi ajar dan ingatan yang lama pada otak.

Hal ini didukung oleh penelitian Reni Pebriani dkk (2016), pada penelitian yang berjudul

"Penerapan Pendekatan Concrete Representational Abstract Berbasis Masalah terhadap Kemampuan Pemecahan Masalah Matematis Siswa di Gugus 40 Kecamatan penyileukan" yang menyatakan bahwa penerapan Pendekatan Concrete Representational Abstract ini dapat meningkatan kemampuan pemecahan masalah matematis siswa. penulis tertarik untuk melakukan penelitian tentang strategi Concrete Representational Abstract terhadap pemahaman konsep pada siswa SMP. Karena pada penelitian Reni hanya menjelaskan peningkatan pemecahan masalah matematika pada SD namun belum dijelaskan apakah strategi Concrete Representational Abstract mampu meningkatkan pemahaman konsep pada siswa SMP, yang mana pemahaman konsep merupakan salah satu dasar dari pemecahan masalah.

Berdasarkan uraian tersebut, diduga dengan strategi Concrete Representational Abstract dapat meningkatkan pemahaman konsep matematika siswa. Untuk mengetahui kebenaran tersebut, perlu dilakukan penelitian dengan melakukan eksperimen terhadap pengaruh strategi Concrete Representational Abstract dalam meningkatkan pemahaman konsep matematika. Oleh karena itu, penulis termotivasi melakukan penelitian yang berjudul "Pengaruh Strategi Concrete Representational Abstract (CRA) terhadap Pemahaman Konsep Matematika Siswa Kelas VII SMP Negeri 3 Dawan".

Berdasarkan latar belakang yang telah dipaparkan, dapat dirumuskan permasalahan penelitian, yaitu "Apakah pemahaman konsep matematika siswa yang mengikuti pembelajaran dengan strategi Concrete Representational Abstract lebih baik daripada siswa yang mengikuti strategi pembelajaran konvensional?

Tujuan yang ingin dicapai dari penelitian ini adalah untuk mengetahui 
apakah pemahaman konsep matematika siswa yang mengikuti pembelajaran dengan strategi Concrete Representational Abstract lebih baik daripada siswa yang mengikuti strategi pembelajaran konvensional.

\section{METODE}

Penelitian ini merupakan penelitian eksperimen dalam katagori penelitian eksperimen semu (quasi experiment). Penelitian eksperimen semu dapat digunakan untuk melihat pengaruh yang ditimbulkan dari perlakuan berbeda yang diberikan pada masing-masing kelompok, dimana peneliti tidak dapat mengontrol semua variabel dan kondisi eksperimen secara ketat (Sugiyono,2015). Penelitian ini bertujuan untuk menguji pengaruh strategi Concrete Representational Abstract terhadap pemahaman konsep matematika siswa Kelas VII SMP negeri 3 Dawan.

Dalam penelitian ini, subjek penelitiannya adalah seluruh siswa Kelas VII SMP Negeri 3 Dawan. Banyaknya anggota populasi dalam penelitian ini adalah 124 siswa yang tersebar ke dalam empat kelas, yaitu kelas VII A, VII B, VII C, VII D. Sebaran anggota populasi dalam tiap kelas dapat dilihat pada Tabel 3.1 berikut ini.

Tabel 3.1 Populasi Penelitian

\begin{tabular}{c|c|c}
\hline No & Kelas & Banyak Siswa (orang) \\
\hline 1 & VII A & 32 \\
\hline 2 & VII B & 31 \\
\hline 3 & VII C & 31 \\
\hline 4 & VII D & 30 \\
\hline \multicolumn{2}{|c|}{ Jumlah } & $\mathbf{1 2 4}$ \\
\hline
\end{tabular}

Sumber: Tata Usaha SMP Negeri 3 Dawan

Pengambilan sampel dalam penelitian ini dilakukan dengan teknik cluster random sampling yaitu pemilihan sampel bukan didasarkan pada individual, tetapi lebih didasarkan pada kelompok, daerah, atau kelompok subjek yang secara alami berkumpul bersama (Suryabrata,2006). Penggunaan teknik cluster random sampling dalam penentuan sampel dikarenkaan sampel dalam penelitian ini adalah kelompok siswa dalam bentuk kelas - kelas yang sudah ada.

Sebelum melakukan pengambilan sampel secara acak pada kelas VII, akan digunakan uji kesetaraan dengan menggunakan Analisis Varian (ANAVA) satu jalur. Data yang digunakan uji kesetaraan adalah Nilai Tengah Semester Matematika siswa kelas VII di semester ganjil tahun ajaran 2017/2018 karena nilai ulangan tengah semester matematika mencerminkan kemampuan siswa yang sesungguhnya. Uji kesetaraan ini dilakukan dengan menggunakan uji ANAVA satu jalur atau sering disebut uji F.

Variabel bebas dalam penelitian ini adalah strategi pembelajaran, dimana pembelajaran dengan strategi Concrete Representational Abstract yang diterapkan pada kelompok eksperimen dan pembelajaran dengan strategi pembelajaran konvensional diterapkan pada kelompok kontrol, sedangkan variabel terikat dalam penelitian ini adalah pemahaman konsep matematika

Penelitian ini bertujuan untuk mengetahui pengaruh penerapan pendekatan reciprocal teaching.. Rancangan penelitian yang digunakan adalah Post Test Only Control Group Design, di mana kelompok kontrol adalah kelompok yang mendapatkan pembelajaran dengan pendekatan konvensional, sedangkan kelompok eksperimen adalah kelompok yang mendapatkan pembelajaran dengan strategi Concrete Representational Abstract.

Jenis instrumen yang digunakan dalam penelitian ini berupa tes. Instrumen tes berupa data kuantitatif yaitu tes untuk mengukur kemampuan pemahaman konsep matematika siswa. Data yang dikumpulkan pada penelitian ini adalah berupa skor tes pemahaman konsep matematika siswa, yang dikumpulkan melalui tes pemahaman konsep matematika. Tes pemahaman konsep matematika yang dipergunakan berupa tes uraian.

Menghindari unsur subyektivitas dan memudahkan dalam memberikan nilai untuk tes pemahaman konsep siswa, maka ditentukan rubrik penskoran. Seperti yang telah dibahas sebelumnya, indikator pemahaman konsep yang digunakan dalam penelitian ini adalah indikator yang dikembangkan oleh NCTM yaitu: (1) Describe concepts in their own words (menyatakan konsep dalam kata-kata 
sendiri); (2) Identify or give exampl es and nonexamples of concepts (mengidentifikasi atau memberi contoh atau bukan contoh dari konsep); (3) Use concepts correctly in a variety of situations (mengaplikasikan/menggunakan konsep dengan benar dalam berbagai situasi). Indikator ini yang dijadikan pedoman dalam penyusunan rubrik penskoran tes pemahaman konsep matematika siswa.

Tes pemahaman konsep matematika siswa yang telah disusun diujicobakan untuk mendapatkan gambaran secara empirik tentang kelayakan tes tersebut sebelum dipergunakan sebagai instrumen penelitian. Hasil uji coba dianalisis lebih lanjut untuk mendapatkan validitas dan reliabilitas tes. Hal ini dilakukan karena instrumen penelitian akan dikatakan baik jika sudah memenuhi dua persyaratan penting yaitu valid dan reliabel.

Setelah kelas sampel diberikan perlakuan, kemudian dilakukan pengujian terhadap hipotesis yang diajukan. Data yang digunakan adalah pemahaman konsep matematika yang dinyatakan oleh skor tes pemahaman konsep matematika dari kedua kelompok sampel. Sebelum dilakukan pengujian pada hipotesis, maka data yang diperoleh perlu diuji normalitas sebaran data dan homogenitas variansnya

Uji normalitas digunakan untuk menentukan data dalam kelompok sampel berasal dari populasi yang normal atau tidak. Apabila data berdistribusi normal, maka uji hipotesis dapat dilakukan. Pengujian normalitas sebaran skor prestasi belajar matematika menggunakan teknik Kolmogorov-Smirnov. Uji KolmogorovSmirnov dapat digunakan untuk sampel besar maupun sampel kecil dan berupa data interval. Uji homogenitas varians untuk kedua kelompok digunakan Uji $F$. Uji $F$ ini digunakan karena peneliti hanya menggunakan dua kelompok penelitian sehingga untuk memudahkan mengetahui homogenitas sebaran data maka digunakan uji $\mathrm{F}$.

Apabila diperoleh sampel berdistribusi normal dan memiliki varians yang homogen, dilanjutkan dengan pengujian hipotesi. Untuk menguji hipotesis nol $\left(H_{0}\right)$ pada penelitian ini akan digunakan uji-t satu ekor (ekor kanan) dengan taraf signifikan $5 \%$ t-test, yang digunakan dengan rumus sebagai berikut:

$$
t_{\text {hit }}=\frac{\bar{Y}_{1}-\bar{Y}_{2}}{S \sqrt{\frac{1}{n_{1}}+\frac{1}{n_{2}}}}
$$

\section{HASIL DAN PEMBAHASAN}

Data pemahaman konsep matematika siswa yang dperoleh melalui post-test untuk kelompok eksperimen dan kelompok kontrol ditunjukkan pada lampiran 18. Rangkuman analisis data pemahaman konsep matematika siswa pada kedua kelompok sampel data dilihat pada tabel 4.1 berikut.

Tabel 4.1 Rangkuman Analisis Data Pemahaman Konsep Matematika Siswa

\begin{tabular}{|c|c|c|}
\hline \multirow{2}{*}{ Variabel } & \multicolumn{2}{|c|}{ Sampel } \\
\cline { 2 - 3 } & $\begin{array}{c}\text { Kelas } \\
\text { Eksperimen }\end{array}$ & $\begin{array}{c}\text { Kelas } \\
\text { Kontrol }\end{array}$ \\
\hline $\begin{array}{c}\text { Banyak } \\
\text { Siswa }(n)\end{array}$ & 32 & 31 \\
\hline Rata-rata $(\bar{X})$ & 16,03 & 13,6 \\
\hline $\begin{array}{c}\text { Standar } \\
\text { Deviasi }(S D)\end{array}$ & 3,18 & 3.42 \\
\hline
\end{tabular}

Berdasarkan Tabel 4.1 terlihat bahwa nilai rata - rata nilai pemahaman konsep matematika siswa pada kelompok eksperimen yang dibelajarkan dengan strategi pembelajaran Concrete Representational Abstract lebih baik daripada rata - rata nilai pemahaman konsep matematika siswa pada kelompok kontrol yang dibelajarkan dengan strategi pembelajaran konvensional.

Untuk mengetahui apakah terdapat pengaruh strategi pembelajaran Concrete Representational Abstract terhadap pemahaman konsep matematika siswa, perlu pengujian terhadap hipotesis. Sebelum uji hipotesis dilakukan, terlebih dahulu dilakukan pengujian terhadap normalitas sebaran data dan homogenitas varians data pemahaman konsep matematika siswa. Berikut uraian mengenai hasil pengujian normalitas dan homogenitas varians data pemahaman konsep matematika siswa. 
Uji normalitas yang digunakan dalam penelitian ini adalah dengan menggunakan teknik Kolmogorov-Smirnov. Data dikatakan berdistribusi normal apabila nilai $D_{\text {hitung }}<$ $D_{\text {tabel }}$ (perhitungan lengkap dapat dilihat pada lampiran 18). Adapun rangkuman hasil hasil pengujian normalitas sebaran data skor pemahaman konsep matematika siswa untuk kedua kelompok sampel dengan uji Kolmogorov-Smirnov dapat dilihat pada tabel 4.2 berikut.

Tabel 4.2 Rangkuman Hasil Uji Normalitas Skor Pemahaman KonsepMatematika Siswa

\begin{tabular}{|c|c|c|c|}
\hline $\begin{array}{c}\text { Kelompok } \\
\text { Sampel }\end{array}$ & $\mathbf{D}_{\text {hitung }}$ & $\mathbf{D}_{\text {tabel }}$ & Ket \\
\hline Eksperimen & 0,1507 & 0,1542 & Normal \\
\hline Kontrol & 0,1423 & 0,1565 & Normal \\
\hline
\end{tabular}

Dari Tabel 4.2 diatas, terlihat bahwa $D_{\text {hitung }}$ pada kedua kelompok sampel kurang dari $D_{\text {tabelpada kelompok yang }}$ bersangkutan. Dengan demikian $\mathrm{H}_{0}$ diterima dengan kesimpulan bahwa data pemahaman konsep matematika siswa berasal dari populasi yang berdistribusi normal.

Homogenitas varians data pemahaman konsep matematika siswa dianalisis dengan Uji Levence.Data dikatakan homogen jika $\mathrm{W}<\mathrm{F}_{\text {tabel. }}$. Adapun rangkuman hasil pengujian homogenitas varians sebaran data skor pemahaman konsep matematika siswa untuk kelompok sampel dengan Uji Levence dapat dilihat pada Tabel 4.3 berikut.

Tabel 4.3 Rangkuman Hasil Uji Homogenitas Varians Skor Pemahaman Konsep Matematika Siswa

\begin{tabular}{|l|l|l|l|}
\hline $\begin{array}{l}\text { Kelompok } \\
\text { Sampel }\end{array}$ & Varians & W & Ftabel \\
\cline { 1 - 2 } Eksperimen & 16,0313 & 0,019 & 3,9802 \\
\hline Kontrol & 13,5806 & & \\
\hline
\end{tabular}

Dari tabel 4.3 di atas, dapat dilihat bahwa $W<F_{\text {tabel }}$. dengan demikian $\mathrm{H}_{0}$ diterima dengan kesimpulan bahwa kedua kelompok sampel mimiliki varians data pemahaman konsep matematika yang homogen.
Hasil Uji normalitas dan uji homogenitas yang telah dilakukan memperlihatkan bahwa data dari kelompok eksperimen dan kelompok kontrol berasal dari populasi yang berdisttribusi normal dan variansnya homogen. Karena uji prasyarat sudah terpenuhi, maka pengujian hipotesis dapat dilakukan dengan menggunakan Uji- $t$ satu ekor untuk melihat ada tidaknya perbedaan pemahaman konsep matematika siswa yang dibelajarkan dengan strategi Concrete Representational Abstract dan pemahaman konsep matematika siswa yang mengikuti pembelajaran konvensional.

Rangkuman hasil pengujian data pemahaman konsep matematika siswa dengan menggunakan Uji-t disajikan pada Tabel 4.4 berikut.

Tabel 4.4 Rangkuman Hasil Uji-t Data Pemahaman Konsep
Matematika Siswa

\begin{tabular}{|l|l|l|l|l|l|l|}
\hline Kelas & $\mathrm{n}$ & $\bar{X}$ & $S_{\text {gab }}$ & $S_{\text {gab }}^{2}$ & $t_{\text {hit }}$ & $t_{\text {tabel }}$ \\
\hline Eks & 32 & 16,03 & 3,31 & 10,9 & 2,94 & 1,99 \\
\hline Kontrol & 31 & 13,58 & & 3 & & \\
& & & & & & \\
\hline \multicolumn{78}{|c|}{ herdasarkan hasil perhitungan pada }
\end{tabular}
tabel 4.4 di atas, diperoleh bahwa nilai $t_{\text {hitung }}>t_{\text {tabel }}$. Dengan demikian $H_{0}$ ditolak. Sehingga dapat disimpulkam bahwa pemahaman konsep matematika siswa kelas VII SMP Negeri 3 Dawan yang mengikuti pembelajaran dengan strategi Concrete Representational Abstract lebihbaik dari pada pemahaman konsep matematika siswa yang mengikuti strategi pembelajaran konvensional.

Berdasarkan hasil analisis terhadap skor pemahaman konsep matematika siswa, diketahui bahwa rata - rata skor pemahaman konsep matematika siswa pada kelompok eksperimen adalah 16,0313, sedangkan rata - rata skor pemahaman konsep matematika siswa pada kelompok kontrol adalah 13,5806. Hal ini menunjukkan bahwa rata - rata skor pemahaman konsep matematika siswa pada kelompok eksperimen lebih baik dibandingkan dengan rata - rata pemahaman konsep matematika pada kelompok kontrol. Dari hasil uji hipotesis menggunakan Uji-t diperoleh bahwa $t_{\text {hitung }}=2,9418>t_{\text {tabel }}=1,9996$ untuk 
$\alpha=5 \%$ sehingga $H_{0}$ ditolak dan $H_{1}$ diterima.

Dengan kata lain, pemahaman konsep matematika siswa kelas VII SMP Negeri 3 Dawan yang mengikuti pembelajaran dengan strategi Concrete Representational Abstract lebih baik dari pemahaman konsep matematika siswa yang mengikuti pembelajaran dengan strategi konvensional. Ini berarti bahwa strategi Concrete Representational Abstract dapat meningkatkan pemahaman konsep matematika siswa.

Hal ini terjadi karena strategi Concrete Representational Abstract adalah suatu strategi yang menyenangkan sehingga siswa merasa lebih nyaman dalam pembelajaran dan lebih tertarik untuk memahami konsep-konsep matematika jika mereka saling berdiskusi dengan teman. Tahapan-tahapan dari strategi Concrete Representational Abstract dapat membantu siswa lebih memahami konsep-konsep dari matematika yang telah diajarkan oleh guru. Contohnya melalui tahapan concrete yang membuat suasana kelas menjadi lebih santai dan menyenangkan karena siswa disini belajar melalui benda - benda nyata yang ada disekelilingnya sehingga mempermudah siswa mengorganisasikan informasi yang merefleksikan pemikiran, permasalahan, perhatian serta hubungan hubungan dengan pembelajaran sebelumnya sehingga siswa dapat lebih lama mengingat konsep -konsep materi yang telah diperlajarinya. Pembelajaran dengan menggunakan strategi Concrete Representational Abstract menggunakan metode diskusi berkelompok dengan anggota sebanyak dua sampai tiga siswa, dimana dengan diskusi secara berkelompok, siswa mampu berbagi informasi yang diketahui dengan rekan sebayanya, selain itu belajar kelompok dapat meningkatkan motivasi belajar siswa. Dengan diskusi berkelompok siswa diberikan kesempatan untuk mengajarkan dan menjelaskan informasi atau konsep kepada anggota kelompok sehingga dapat membantu memperkuat penguasaan terhadap suatu konsep atau informasi tertentu. Diskusi kelompok juga dapat melatih sikap demokratis siswa untuk berperan aktif dalam mengajukan argumentasinya, mencermati pendapat teman, bertukar pikiran, membenahi konsep yang masih keliru serta melengkapi pengetahuannya. Selain itu strategi Concrete Representational Abstract juga menyajikan tahapan representational, dimana guru bersama siswa membahas apa yang telah dipelajari dan meminimalkan kesalahpahaman jawaban siswa dengan ditahapan ini siswa diminta untuk menggambarkan suatu model permasalahan yang didapat dari tahapan sebelumnya, ketika sudah bisa menggambarkan permasalaahan tersebut secara tidak langsung berarti siswa tersebut sudah mampu memahami konsep dalam pembelajarannya, sehingga siswa akan lebih bersemangat untuk mempelajari pelajarannya dan akan mencari cara lebih untuk memahami konsep - konsep matematika pada pertemuan berikutnya. Selain itu pada tahap abstract siswa dituntut untuk bisa membuat simbol matematika untuk menyelesaikan permasalahannya, dari tahapan - tahapan sebelumnya, jika sudah bisa mebuat simbol matematika siswa dianggap sudah mampu memahami konsep - konsep matematika. Pada akhir pembelajaran guru mengadakan perayaan atau integrasi terhadap proses pembelajaran siswa baik secara individumaupun kelompok, hal ini biasanya dilakukan dengan memberikan tepuk tangan maupun hadiah - hadiah pada siswa yang dianggap berprestasi pada saat pembelajaran, hal ini dimaksudkan agar siswa lebih giat belajar dan menjadi motivasi untuk lebih baik dari sebelumnya.

Peran guru dalam penerapan strategi Concrete Representational Abstract adalah sebagai fasilitator dalam proses pembelajaran, yaitu mulai dari siswa diminta untuk membuat permasalahan dari beda benda nyata di sekitarnya, meubah permasalahan tersebut ke gambar dan bisa menyimbolkannya menyediakan kondisi yang kondusif dan menyenangkan bagi siswa sehingga muncul motivasi dalam diri siswa untuk memahami konsep pembelajaran sehingga akan tercapai pula optimalisasi konsep matematika, baik dikalangan siswa berkemampuan tinggi, sedang maupun siswa dengan kemampuan rendah. Keunggulan - keunggulan inilah 
yang membuat strategi Concrete Representational Abstract menjadi lebih menarik dan mampu mengkoordinir siswa, sehingga mampu mendorong meningkatnya pemahaman konsep matematika siswa. Dengan demikian, pembelajaran yang dilakukan oleh siswa akan memberikan pengalaman sehingga siswa mampu untuk untuk mengeksperikan ide - ide matematika, memahami, menginterprestasi, dan mengevaluasi ide - ide matematika dan mampu menggunakan simbol atau istilah matematika.

Berdasarkan uraian diatas, ditunjukkan dengan hasil post test siswa yang dibelajarkan dengan strategi Concrete Representational Abstract memiliki rata rata nilai pemahaman konsep matematika siswa yang lebih baik daripada siswa yang belajarkan dengan strategi konvensional.

Diharapkan strategi Concrete Representational Abstract dapat dikembangkan dan diterapkan dalam kegiatan pembelajaran di Indonesia yang nantinya dapat memberikan dampak yang baik bagi pembangunan pendidikan di Indonesia pada umumnya dan pada proses pembelajaran matematika pada khusunya.

\section{SIMPULAN DAN SARAN}

Berdasarkan rumusan masalah, hasil analisis data, dan pembahasan penelitian yang telah diurakan di depan, dapat disimpukan bahwa pemahaman konsep matematika siswa kelas VII SMP Negeri 3 Dawan yang dbelajarkan dengan strategi Concrete Representational Abstract lebih baik daripada pemahaman konsep matematika siswa kelas VII SMP Negeri 3 Dawan yang mengikuti strategi pembelajaran konvensional. Dengan demikian dapat disimpulkan bahwa pemahaman konsep matematika siswa yang dbelajarkan dengan strategi Concrete Representational Abstract lebih baik daripada pemahaman konsep matematika siswa yang dibelajarkan dengan strategi pembelajaran konvensional.

Adapun saran yang disampaikan berdasarkan hasil penelitian yang telah dilakukan adalah kepada peneliti lain yang tertarik, disarankan untuk melakukan penelitian terhadap strategi Concrete Representational Abstract dengan populasi yang lebih besar dan materi pembelajaran yang lebih luas untuk mengetahui pengaruh penerapan strategi Concrete Representational Abstract dalam pembelajaran matematika secara lebih mendalam. Selanjutnya untuk praktisi pendidikan matematika, khususnya guru pelajaran matematika diharapkan dalam pembelajaran di kelas untuk menerapkan strategi Concrete Representational Abstract sebagai salah satu alternative pembelajaran mengigat pengaruh positif yang diberikan model ini terhadap kemampuan komunikasi matematika siswa

\section{DAFTAR PUSTAKA}

Agustin, M. 2011. Permasalahan Belajar dan Inovasi Pembelajaran. Bandung: PT Revika Aditama.

Departemen Pendidikan Nasional. 2006. Peraturan Pemerintah RI No. 22 Tahun 2006 Tentang Standar Nasional Pendidikan. Jakarta: Cemerlang.

Hadujo, H. 2003. Pengembangan Kurikulum Pembelajaran Matematika. Malang: JICA

Pebriani. Dkk. 2016. Penerapan Pendekatan Concrete Representational Abstract (CRA) Berbasis Masalah terhadap Kemampuan Pemecahan Masalah Matematis Siswa di Gugus 40 Kecamatan pennyileukan

Sugiyono. 2013. Metode Penelitian Pendidikan (Pendekatan Kualitatif, Kuantitatif, 23.

Suryani, Nunuk dan Agung, Leo. 2012. Strategi Belajar Mengajar. Yogyakarta: Penerbit Ombak. 